\title{
PENGARUH BRAND AWARENESS, PERCEIVED QUALITY DAN CONSUMER ATTITUDE TERHADAP PURCHASE INTENTION PRODUK SKIN CARE TELAAH PADA KONSUMEN PRIA DI INDONESIA
}

\author{
Kenny \\ Program Studi Magister Manajemen Universitas Tarumanagara \\ kennyoey@gmail.com \\ Rezi Erdiansyah \\ Program Studi Magister Manajemen Universitas Tarumanagara \\ Masuk : 30-11-2020, revisi : 15-12-2020 diterima untuk diterbitkan : 16-12-2020
}

\begin{abstract}
This research is proposed to find out whether there is relationship between brand awareness, perceived quality, and consumer attitude, with purchase intention in Nivea Men Crème Product with 4 hypotheses that will be tested using the Structural Equation Model. The sample in this study consisted of 162 respondents who were men in Indonesia who had used, seen, and knew the Nivea brand. The result of the analysis that using AMOS ver. 25 proven that brand awareness, perceived quality and consumer attitude simultaneously have an influence on Nivea Men Crème purchase intentions in Indonesian's men market.
\end{abstract}

Keywords: Brand Awareness, Perceived Quality, Consumer Attitude, Purchase Intention

\begin{abstract}
Abstrak: Penelitian ini bertujuan untuk mengetahui apakah terdapat minat beli pria Indonesia terhadap produk Nivea Men Crème yang dipengaruhi oleh brand awareness, perceived quality dan consumer attitude. Model teoritis dalam penelitian ini disajikan dengan 4 hipotesis yang akan diuji menggunakan Structural Equation Model. Sampel dalam penelitian ini berjumlah 162 responden laki-laki di Indonesia yang pernah melihat, mengenal merek Nivea. Hasil analisis metode penelitian AMOS ver.25 (Paket Statistik Ilmu Sosial) membuktikan bahwa brand awareness, perceived quality dan consumer attitude secara simultan berpengaruh terhadap niat beli Nivea Men Crème di pasar pria Indonesia.
\end{abstract}

Kata Kunci: Brand Awareness, Perceived Quality, Consumer Attitude, Purchase Intention

\section{PENDAHULUAN}

Perkembangan pasar untuk produk perawatan kulit yang terus berkembang khususnya untuk pasar Indonesia membuat banyak perusahaan berlomba untuk mengeluarkan produk perawatan kulit dengan berbagai solusi dan keunggulan yang ditawarkan. Merupakan sebuah tantangan untuk para marketers untuk masuk dan mengetahui apa faktor inti seseorang memiliki keinginan hingga melakukan pembelian prudk tersebut. Menurut Kotler dan Keller (2015) dalam mengeksekusi keinginan pembelian biasanya konsumen akan memikirkan lima sub-keputusan, antara lain merek, dealer, jumlah, waktu dan cara pembayaran. Tren perawatan kulit tidak hanya digemari oleh para wanita di Indonesia untuk mempercantik diri, sekarang ini perawatan kulit untuk pria juga memiliki potensi pasar yang tinggi, pernyataan ini didukung oleh L'Oreal (2018). Pria di Indonesia memiliki peranan penting dalam hal produk kecantikan dan tren ini telah menyebabkan pertumbuhan yang dinamis dan baru di sektor perawatan wajah.

Dalam penelitian ini peneliti ingin mengangkat bagaimana sikap seseorang terhadap sebuah merek dapat mempengaruhi mereka hingga memiliki rasa ketetarikan untuk melakukan pembelian (purchase intention). Kim dan Hunter (1993) dan (Huang et al., 2004) mengungkapkan kebanyakan model behavioral menjelaskan hubungan sebab akibat dari sikap (attitude) melalui purchase intention untuk mengetahui sikap yang sesunggguhnya. Purchase intention atau keinginan membeli dapat menjadi hasil prediksi dari sikap (attitude) konsumen. 
Berdasakan uraian-uraian di atas, maka peneliti tertarik untuk mengangkat masalah penelitian mengenai bagaimana sikap konsumen (customer attitude), kesadaran merek (brand awareness) dan penilaian kualitas (perceived quality) menjadi penentu seseorang melakukan pembelian. Dengan demikian, penelitian ini diberi judul "Pengaruh Brand Awareness, Perceived Quality dan Consumer Attitude terhadap Purchase Intention Produk Skin Care Telaah pada Konsumen Pria di Indonesia".

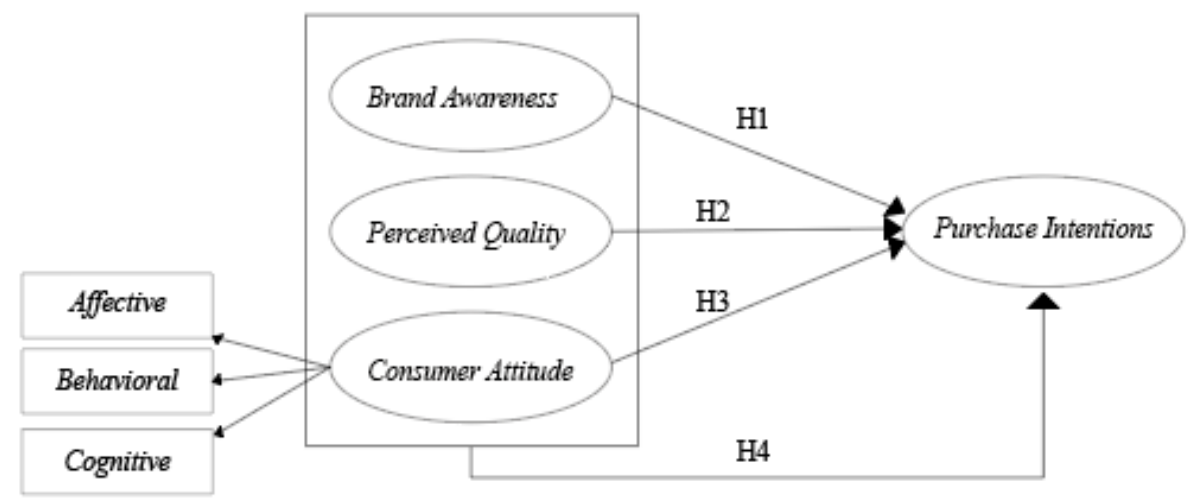

Gambar 1

Model Penelitian

Sumber: Dokumen Peneliti

\section{HIPOTESIS}

\section{Pengaruh Brand Awareness terhadap Purchase Intention}

Hasil penelitian Lee et al., (2019) yang meneliti mengenai purchase intention terhadap perawatan kulit pada pria mengungkapkan bahwa adanya pengaruh positif antara brand awareness terhadap purchase intention. Wang dan Li (2012) juga mengungkapkan bahwa adanya hubungan positif antara brand awareness terhadap Purchase intention. Chi et al., (2009) juga mengungkapkan apabila brand awareness meningkat maka purchase intention juga akan meningkat, sehingga ada pengaruh positif antar keduanya.

H 1: Brand Awareness berpengaruh positif terhadap Purchase Intention.

\section{Pengaruh Perceived Quality tehadap Purchase Intention}

Hasil penelitian milik Chi et al. (2009) mengungkapkan adanya pengaruh positif antara perceived quality terhadap purchase intention. Wang dan Li (2012) juga mengungkapkan bahwa adanya pengaruh positif antara perceived quality terhadap purchase intention. Hasil penelitian Cheng et al. (2014) mengenai license merchandise menyebutkan adanya pengaruh positif antara perceived quality teradap purchase intention. Hasil dari beberapa penelitian studi tersebut menghasilkan beberapa hipotesis yang akan diuji dalam penelitian ini adalah:

H 2: Perceived Quality berpengaruh positif terhadap Purchase Intention.

\section{Pengaruh Consumer Attitude terhadap Purchase Intention}

Dalam penelitian milik Tang et al. (2014) menyebutkan adanya pengaruh positif antara sikap seseorang terhadap keinginan untuk membeli. Penelitian milik Bruhn et al., (2012) menyatakan bahwa sikap seseorang terhadap merek mempengaruhi secara positif keinginan seseorang untuk membeli produk tersebut. Penelitian Kudeshia \& Kumar (2017) menyebutkan adanya pengaruh positif antara attitude terhadap Purchase Intention. Dalam penelitian ini untuk mengukur consumer attitude peneliti menggunakan teori $\mathrm{ABC}$ yang dimana A sebagai Affective dijelaskan sebagai perasaan konsumen terhadap sebuah merek, B sebagai Behavior atau perilaku konsumen terhadap sebuah merek dan $\mathrm{C}$ berdiri untuk Cognitive atau pengetahuan konsumen terhadap sebuah merek.

Hasil dari beberapa penelitian studi tersebut menghasilkan beberapa hipotesis yang akan diuji dalam penelitian ini adalah:

H 3: Consumer Attitude berpengaruh positif terhadap Purchase Intention 


\section{Pengaruh Brand Awareness, Perceived Quality, Consumer Attitude terhadap Purchase Intentions secara simultan}

Dalam penelitian ini dilakukan analisa regresi untuk mengukur sejauh mana pengaruh brand awareness, perceived quality, consumer attitude secara simultan untuk meningkatkan niat beli konsumen purchase intentions.

H4: Brand awareness, perceived quality, consumer attitude memiliki pengaruh secara simultan terhadap purchase intentions.

\section{METODE PENELITIAN}

Data dalam penelitian ini didapatkan dari hasil penyebaran kuisioner kepada responden satu kali dalam satu periode atau disebut juga single cross sectional design. Dalam penelitian ini, peneliti menyebarkan kuisioner kepada 162 responden dengan 22 pertanyaan yang diuji. Dalam pengukuran di penelitian ini menggunakan skala likert 5. Responden akan diberikan lima pilihan sebagai jawaban sesuai yang ada pada skala likert 5 yaitu: Sangat Setuju (SS), Setuju (S), Netral (N), Tidak Setuju (TS), dan Sangat Tidak Setuju (STS). Kuisioner akan disebarkan kepada responden yang sudah memenuhi syarat yaitu pria yang berdomisili di Indonesia dan pernah melihat, mengetahui, membeli, dan menggunakan produk Nivea sebelumnya. Program statistical product and service solutions (SPSS) versi 15 dan software AMOS Ver. 25 untuk Structural Equation Model (SEM) merupakan teknik dan aplikasi yang digunakan dalam pengolahan data pada penelitian ini.

\section{HASIL TEMUAN}

Dalam penelitian ini responden adalah pria yang tinggal di Indonesia dengan mayoritas range umur dari umur 24 - 29 tahun (57\%) dengan jumlah 99 pria. Mayoritas responden merupakan Pekerja atau karyawan dengan jumlah 115 responden atau sebesar 65,7\% dari total responden. $72.6 \%$ responden menjenjang pendidikan $\mathrm{S} 1$ dan setara. Untuk pengeluaran pribadi saat membeli produk perawatan kulit mayoritas responden mengeluarkan budget sebesar Rp50.000 - Rp100.000,- perbulan sebanyak 38 responden (21.7\%) disusul dengan range budget sebesar Rp150.000 - Rp 200.000,- perbulan dengan jumlah responden sebesar 37 orang (21.1\%). Mayoritas responden mendapatkan refrensi produk perawatan kulit yang digunakan dari orang tua, kerabat, dan teman sekitar dengan besaran $37.1 \%$ dari total responden atau sebanyak 65 orang. Berdasarkan data yang diperoleh, mayoritas responden menghadapi masalah kulit berminyak disusul dengan berjerawat dan komedo. Hal ini wajar adanya mengingat responden tinggal di Indonesia dimana dikenal sebagai Negara tropis di Asia.

\section{Tabel 1}

Hasil Pengujian Hipotesis

\begin{tabular}{|c|c|c|c|c|}
\hline Hipotesis & Path & Standard Coef. & P-Value, $p \leq 0,05$ & Kesimpulan \\
\hline H1: & $\begin{array}{c}\text { Brand Awareness (X1) } \\
\downarrow \\
\text { Purchase Intention (Y) }\end{array}$ & 0.322 & 0.022 & Diterima \\
\hline $\mathrm{H} 2$ : & $\begin{array}{c}\text { Perceived Quality (X2) } \\
\downarrow \\
\text { Purchase Intention (Y) }\end{array}$ & 0.285 & 0.047 & Diterima \\
\hline H3: & $\begin{array}{c}\text { Consumer Attitude (X3) } \\
\downarrow \\
\text { Purchase Intention (Y) }\end{array}$ & 0.676 & 0.024 & Diterima \\
\hline
\end{tabular}

Sumber: Data Primer, hasil pengolahan data SPSS

\section{DISKUSI}

Setelah melewati berbagai analisis terhadap measurement model, Hasil uji model struktural menunjukkan bahwa adanya pengaruh brand awareness terhadap purchase intention sesuai dengan hasil yang terdapat di penelitian milik Lee, et al. (2019) yang menunjukan adanya pengaruh positif dari brand awareness terhadap purchase intention. ingginya brand 
awareness atau kesadaran konsumen terhadap sebuah merek tentu menjadi salah satu faktor yang mempengaruhi keinginan seseorang untuk melakukan pembelian. Konsumen akan sungkan membeli produk yang belum dikenali.

Hasil uji model struktural pada penelitian ini menunjukan perceived quality memiliki pengaruh positif terhadap purchase intention. Dengan nilai standardized coefficients 0.285 dan nilai $p$-value 0.047 yang memenuhi syarat yaitu $p$-value $\leq 0,05$. Penelitian ini sejalan dengan hasil penelitian milik Cheng et al. (2014) mengenai license merchandise menyebutkan adanya pengaruh positif antara perceived quality teradap purchase intention. ketika konsumen merasa sebuah produk memiliki kualitas yang baik maka keinginan konsumen membeli produk tersebut akan lebih tinggi dibandingkan apabila konsumen merasa produk tersebut tidak memiliki kualitas yang baik.

Hasil uji model struktural pada penelitian ini menunjukan consumer attitude memiliki pengaruh positif terhadap purchase intention. Dengan nilai standardized coefficients 0.676 dan nilai $p$-value 0.024 yang memenuhi syarat yaitu $p$-value $\leq 0,05$. Hasil uji ini didukung dari hasil penelitian terdahulu milik Rezai, et al. (2019) yang membahas mengenai makanan natural menemukan bahwa consumer attitude memiliki pengaruh positif terhadap purchase intention. didukung dengan penelitian milik Tang et al. (2014) yang menyebutkan adanya pengaruh positif antara sikap seseorang terhadap keinginan untuk membeli.

Untuk mengukur pengaruh setiap varibel bersifat simultan atau tidak telah dilkaukan uji $F$ (uji simultan) untuk melihatisêpisama (serentak) mempunyai pengaruh yang signifikan terhadap variabel dependen. Pada pengujian secara simultan akan diuji pengaruh ketiga variabel independen secara bersama-sama terhadap variabel dependen. Melihat nilai FHitung sebesar 75.769 atau sebesar 2.65 pada Ftabel. Maka H0 ditolak artinya adanya pengaruh dari variabel- variabel independen (brand awareness, perceived quality dan consumer attitude) secara bersama- sama (simultan) terhadap varibel dependen (purchase intention) pada penelitian ini.

\section{IMPLIKASI MANAJERIAL}

Berdasarkan hasil pengolahan data, terlihat bahwa adanya pengaruh positif antara brand awareness, perceived quality dan consumer attitude terhadap purchase intention. Hasil penelitian ini dapat memberikan masukan bagi brand Nivea sebagai salah satu perusahaan penyedia produk skincare terbesar didunia dalam meningkatkan peluang baru dan meraih pasar baru nantinya. Dilihat dengan keberadaan Nivea Men Crème sebagai produk perawatan kulit pria pertama di Indonesia yang memiliki respon baik dari para responden dan adanya ketertarikan konsumen untuk membeli produk tersebut.

\section{KESIMPULAN}

Berdasarkan analisa hasil penelitian yang menggunakan metode SEM (Structrual Equation Modeling) Maka diambil kesimpulan sebagai berikut:

1. Brand Awareness memiliki pengaruh positif dan signifikan terhadap keputusan pembelian produk Nivea Men Crème.

2. Perceived Quality memiliki pengaruh positif dan signifikan terhadap keputusan pembelian produk Nivea Men Crème.

3. Consumer Attitude memiliki pengaruh positif dan signifikan terhadap keputusan pembelian produk Nivea Men Crème.

4. Brand Awareness, Perceived Quality, Nivea Men Creme memiliki pengaruh positif dan signifikan terhadap keputusan pembelian produk Nivea Men Crème secara simultan. 


\section{SARAN}

Peneliti menyarankan untuk meninjau kembali dimensi- dimensi yang dimiliki consumer attitude, apakah dimensi yang digunakan dalam penelitian ini sudah menggambarkan sebuah consumer attitude atau mungkin ada lagi dimensi lain yang dapat membentuk consumer attitude.

Peneliti juga menyarankan, dalam penelitian selanjutnya dapat meggunakan objek yang berbeda diluar industri skin care dan kosmetik seperti yang digunakan saat ini, apakah model penelitian dan variabel yang digunakan dapat berperan di penelitian industri lain seperti retail, fashion, automotive, hingga perbankan dan makanan serta minuman.

\section{DAFTAR PUSTAKA}

Bruhn, M., Schoenmueller V. \& Schäfer, D. B. (2012). Are social media replacing traditional media in terms of brand equity creation? Management Research Review, 35(9), 770-790.

Cheng, L. J., Yeh, C. C., \& Wong, S. L. (2014). Mediating effects between world games indentification and licensed merchandise. Managing Service Quality, 24(4), 384- 398.

Chi, H. K., Yeh, R. H. \& Yang, Y. T. (2009). The impact of brand awareness on consumer purchase intention: The mediating effect of perceived quality and brand loyalty. The Journal of International Management Studies, 4(1).

Hair, J. F. (2010). Multivariate Data Analysis: A Global Perspective. Pearson Prentice Hall.

Huang, J. H., Lee, B. C. Y., \& Ho, S. H. (2004). Consumer attitude toward Gray Market Group. International Marketing Review, 21(6), 598-1335.

Kotler, P. \& Keller, K. L. (2015). Marketing Management (15 ${ }^{\text {th }}$ ed.). USA: Pearson Education Inc.

Kudeshia, C., \& Kumar, A. (2017). Social eWOM: Does it affect the brand attitude and purchase intention of brands? Management Research Review, 40(3).

Khandelwal, U., \& Bajpai, N. (2013). Measuring consumer attitude through marketing dimensions: A comparative study between metro and non-metro Cities. Jindal Journal of Business Research, 2, 103-185.

Lee, E. J., Goh, M. L. \& Mogh Noor, M. N. (2019). Understanding Purchase Intention of university students toward skin care products. PSU Research Review.

L'Oreal (2018). Indonesian Beauty Attitudes. Retrieved from https://www.loreal.com/en/news/group/indonesian-beauty-attitudes/

Rezai, G., Teng, P. K., Shamsudin, M. N., Mohamed, Z., \& Stanton, J. L. (2017). Effect of perceptual differences on consumer purchase intention of natural functional food. Journal of Agribusiness in Developing and Emerging Economies.

Tang, Y., Wang, X., \& Lu P. (2014). Chinese consumer attitude and purchase intent towards green products. Asia-Pacific Journal of Business Administration, 6(2), 84-96.

Wang, W. T., \& Li, H. M. (2012). Factors influencing mobile services adoption: A brandequity perspective. Internet Research, 22(2), 1066-2243. 